ДОСЛІДЖЕННЯ СТРУКТУРИ ЗОВНІШНЬОЇ ТОРГІВЛІ УКРАЇНИ ТА III СТРАТЕГІЧНI ПРІОРИТЕТИ

\title{
STUDY OF FOREIGN TRADE STRUCTURE OF UKRAINE AND ITS STRATEGIC PRIORITIES
}

УДК 339.5(477)(045)

https://doi.org/10.32843/infrastruct39-13

\section{Мізюк С.Г.}

к.е.н., доцент, завідувач кафедри міжнародної економіки

Національний авіаційний університет Морозова М.A.

студентка

Національний авіаційний університет

Miziuk Svetlana

National Aviation University

Morozova Maryna

National Aviation University
Статтю присвячено дослідженню основних стратегічних пріоритетів України, а саме детальному аналізу динаміки географрічноі структури зовнішньоторговельних операчій країни, для визначення основних напрямів торгівлі після зміни вектору зовнішньоторговельних відносин та поглиблення співпраці з країнами Європейського Союзу. Використовуючи статистичні методи дослідження, проаналізовано структуру експорту України за останні роки, визначено що основними експортними товарами є товари з низькою доданою вартістю та низьким рівнем переробки. Що стосується імпортних товарів, то наша країна купує переважно мінеральні продукти та їх похідні, що робить нашу державу залежною від продуктів паливно-енергетичного комплексу та країн - експортерів даної продукції. Проте, попри позитивні зрушення, експорт до країн Європи залишається незначним, передусім через імпорт товарів із високою доданою вартістю. Ключові слова: стратегічні пріоритети, формалізовані методи, неформалізовані методи, статистичний підхід, структура експорту, імпорт товарів, питома вага торгівлі, сировинний потенціал.

Статья посвящена исследованию основных стратегических приоритетов Украины, а именно детальному анализу динамики географрической структуры внешнеторговых операций страны, для определения основных направлений торговли после смены вектора внешнеторговых отношений. Используя статистические методы исследования, проанализирована структура экспорта Украины. Определено, что основными экспортными товарами Украины являются товары с низкой добавленной стоимостью. Что касается импортных товаров, то Украина покупает преимущественно минеральные продукты и их производные. С потерей привычного для Украины рынка сбыта товаров государство получило возможность углубления отношений со странами Европейского Союза, что привело к небольшому экономическому росту. Однако, несмотря на положительные сдвиги, экспорт в страны Европы остается незначительным, в первую очередь из-за импорта товаров с высокой добавленной стоимостью.

Ключевые слова: стратегические приоритеты, формализованные методы, неформализованные методы, статистический подход, структура экспорта, импорт товаров, удельный вес торговли, сырьевой потенциал.

The article is investigates the main strategic priorities of Ukraine, namely detailed analysis of the dynamics of the geographical structure of country s foreign trade operations, to determine the main directions of trade, after the change of the vector of foreign trade relations, and to deepen cooperation with EU. Using statistical methods, in the article was analyzed the structure of Ukraine's exports in recent years. Determined that the main export commodities Ukraine are products with low added value and low level of processing (in particular it is raw materials, which indicates that our country inefficiently uses available resources by exporting and importing raw materials). Ultimately, competitors are investing in the development of industries, and our government uses the profits to modernize the infrastructure and export raw materials. Relates to imported goods, our country mainly buys mineral products and by-products (such as oil, gas, nuclear reactors), which makes our country dependent not just on the products of the fuel and energy complex, and also dependent on the exporting countries of such products. On the one hand, Ukraine has lost its regular sales market - the Russian Federation, but the state has been given the opportunity to deepen relations with EU countries, which led to the small economic growth compared to the crisis period of 2015-2016. However, despite positive developments, exports to Europe remain low, primarily due to imports of high value-added goods. Ukraine is a commodity country, which has a negative impact on its economic growth. To increase the pace of development of the Ukrainian economy, the government requires restructuring of its export structure. These include the goods diversification, the decline in import of goods, and the increase in exports of high value-added goods. Country can receive a significant percentage of its GDP revenue in the case of the key market segments are developed. A focus on import substitution of fuel and energy resources will help the country reduce its dependence on raw material imports and fluctuations in the foreign market.

Key words: strategic priorities, formalized methods, non-formalized methods, statistical approach, structure of exports, imports of goods, share of trade, raw material potential.

Постановка проблеми. Економічний успіх будь-якої країни залежить від її торгівлі, і це не дивно, адже торгівля займає одне з провідних місць за впливом на економічний розвиток. Міжнародна торгівля долає вузькість ринку, обмеженість ресурсів, збільшує можливість упровадження нових технологій та надає можливість використовувати ресурси країни більш раціонально. Що стосується України, то на нашому ринку присутня низка галузей, які є конкурентоспроможними, однак ці галузі не виробляють товарів із високою доданою вартістю, а, навпаки, пропонують сировину чи готову продукцію, що є вкрай неефективним, адже зазвичай розвинені країни для отримання максимальних прибутків експортують високотехнологічні послуги, зберігаючи свої природні ресурси. Дослідження основних тенденцій зовнішньої торгівлі України, її сучасного стану, динаміки та структури є актуальним питанням, що допоможе визначити основні вектори напряму розвитку зовнішньоторговельних відносин країни.

Аналіз останніх досліджень і публікацій. Питання зовнішньої торгівлі та її впливу на економічний розвиток описане у працях багатьох відомих учених. Сюди можна віднести роботи класиків: А. Сміта, Д. Рікардо, В. Оліна, Е. Хекшера, В. Леонтьєва. Сучасний стан, а також проблеми розвитку міжнародної економіки досліджували такі відомі вчені, як А. Мазаракі, Р. Бондар, Ю. Макогон [2]. Питання аналізу експортно-імпортних операцій 
у контексті зовнішньої торгівлі перебуває у полі зору відомих дослідників та аналітиків. Серед нихО. П`янкова, А. Задоя, Ю. Туницька, В. Тихонова. У працях таких відомих вітчизняних учених, як А. Дунська [11], Ю. Іщук, О. Ралко, Ю. Туницька [10], описано дослідження пріоритетних трансформацій зовнішньої торгівлі України, представлено опис різних проблем експортно-імпортних потоків, а також питання трансформації зовнішньої торгівлі України.

Постановка завдання. Мета статті полягає у дослідженні основних тенденцій зовнішньої торгівлі України, а саме детальному аналізі динаміки географрічної структури зовнішньоторговельних операцій, для визначення основних напрямів торгівлі, а також в аналізі структури зовнішньої торгівлі країни для окреслення стратегічно важливих груп товарів.

Виклад основного матеріалу дослідження. Для України зовнішня торгівля є вкрай важливим питанням. Після розпочатої гібридної війни проти нашої держави, зниження купівельної спроможності населення країни, виникнення обмеженого доступу до звичних ринків збуту товарів, що значно вплинуло на розвиток більшості секторів економіки, починаючи з 2016-2017 рр. відновилося невелике зростання нашої економіки. За останні роки кардинально змінилися географрічні орієнтири зовнішньоторговельних процесів. Якщо раніше значний відсоток зовнішньоторговельних операцій припадав на Російську Федерацію та країни СНД, то після підписання низки економічних угод з ЄС наша країна все більше поглиблює свої відносини з країнами Європейського Союзу. Конкуренція, яка існує на європейському ринку, зумовлює розвиток стратегічних галузей, що позитивно впливає економічне становище країни. Україна належить до країн із великою експортною квотою, але навіть при цьому наша держава значно поступається розвиненим країнам в обсягах експорту на душу населення.

Для встановлення основних стратегічних пріоритетів, тенденцій сучасного стану зовнішньої торгівлі країни прийнято застосовувати низку методів та підходів, які можна розділити на дві основні категорії: нефрормалізовані, або якісні, та фрормалізовані - кількісні. Профресором кафедри міжнародних економічних відносин КНЕУ запропоновано систематизацію методів/підходів до дослідження структури та динаміки зовнішньої торгівлі країни. Досить важливим є застосування будь-яких фрормалізованих методів дослідження, адже це передбачає визначення чинників, які зображають стан та перспективи розвитку зовнішньої торгівлі. Найбільш поширеними є індикативний та індексний методи дослідження (рис. 1).

Індикативний метод ґрунтується на розрахунку основних показників зовнішньої торгівлі, а також їх порівнянні. Індексний метод, що активно застосовується різними вченими, окреслює розрахунок основних індексів, які ґрунтуються на співвідношеннях показників торгівлі. Аналіз збалансованості допомагає класифікувати інформацію щодо зовнішньої торгівлі, охарактеризувати основні тенденції, а також чинники, що впливають на торгівлю. Мінусом даного методу є те, що він дає лише суху статистику і не дає змоги надати будь-які прогнози щодо динаміки показників.

Факторний підхід спирається на виявлення та систематизацію чинників, які впливають на динаміку зовнішньої торгівлі країни. Використовується для оцінки стану, а також для визначення основних перспектив розвитку зовнішньої торгівлі. Даний метод $є$ доволі ефективним засобом для виявлення загальних закономірностей міжнародної спеціалізації країни, особливо в ситуації пошуку нових ринків збуту, через великий обсяг

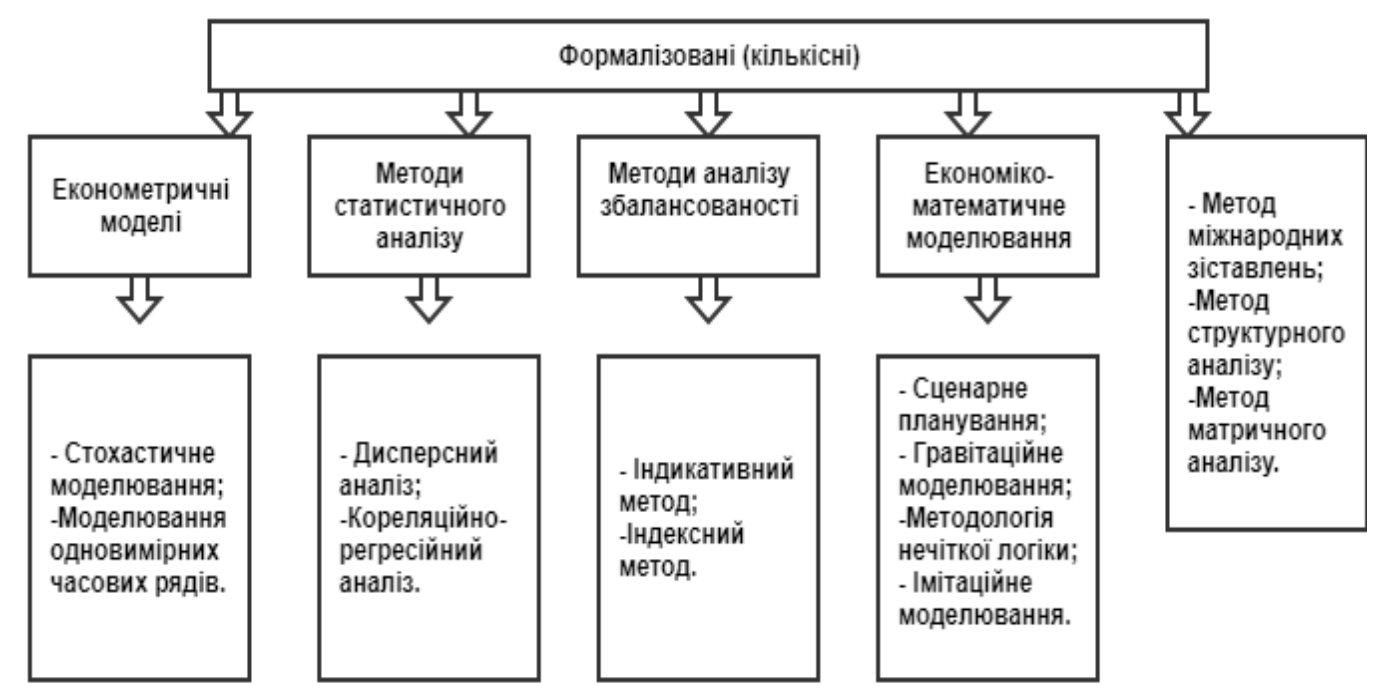

Рис. 1. Формалізовані методи дослідження структури та динаміки зовнішньої торгівлі України [3] 


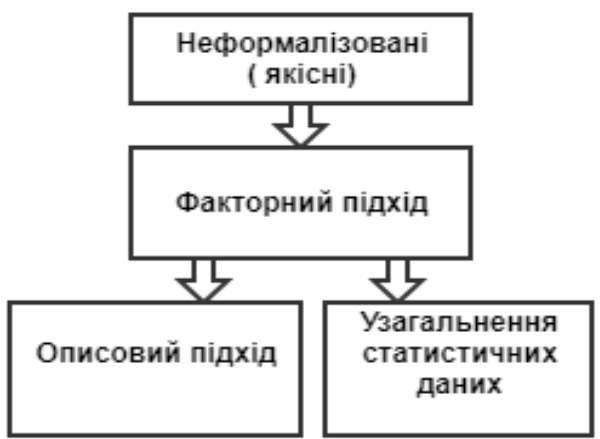

Рис. 2. Неформалізовані методи дослідження структури та динаміки зовнішньої торгівлі України [3]

статистичних даних або ж для виключно описового характеру дослідження.

У нашому разі доцільно застосовувати статистичні методи, основною їхньою перевагою $€$ те, що вони досить надійні. Головне завдання таких методів - це стиснення інформації, оскільки, працюючи з великою кількістю даних, людина не може зробити коректні висновки.

Для детального аналізу, використовуючи базу статистичних даних Державної служби статистики України, представимо структуру експорту нашої країни за останні п`ять років.

3 отриманих даних ми можемо дійти висновку, що друге місце серед товарів, від яких країна отримує найбільше надходжень до ВВП, займають продукти агропромислового комплексу. Україна входить до основних світових експортерів аграрної продукції. Передусім це зернові культури: 15,3\% у 2018 р., що на 20,9\% більше порівняно 32014 р., коли експорт становив 12,1\%. Також значними є обсяги експорту олії - 9,4\% у 2018 р. від загальної кількості порівняно з 7,1\% у 2014 р.
Такого росту вдалося досягти завдяки поглибленій співпраці 3 Європейським Союзом, що дає можливість перейняти досвід ЄС 3 актуальних питань у сорері аграрного сектору, але навіть за таких обставин український експорт сільськогосподарської продукції залишається досить вузько спрямованим.

Перше місце займає експорт недорогоцінних металів, найбільше припадає на чорні метали 21\%, після досить довгого періоду негативної динаміки вперше експорт металів зріс. У 2015-2016 рр. експорт чорних металів тримався на рівні 19,9\%, але навіть після поглиблення торговельних відносин з Європейським Союзом Україні не вдалося досягти тих обсягів експорту, які зберігалися до подій 2014 р., коли частка становила 23,9\% від загального обсягу. Як бачимо, ключовими статтями експорту $є$ товари $з$ низькою доданою вартістю, а також із низьким рівнем переробки. Це свідчить про те, що ми не можемо говорити про перехід на високотехнологічні моделі виробництва, оскільки це не дає змоги зробити загальна продуктивність, тобто структурна перебудова експорту буде вкрай неефективною.

Після втрати одного з найбільших торговельних партнерів змінився вектор зовнішньоторговельних відносин України. Якщо раніше значна частина експортно-імпортних операцій припадала на Російську Федерацію, то після перебудови зовнішньоторговельних орієнтирів Україна отримала шанс поглибити торговельні відносини з країнами Європейського Союзу та Європи у цілому. Для наочного зображення представимо діаграму географрічної структури зовнішньої торгівлі товарами України за останні роки, використовуючи базу статистичних даних країни.

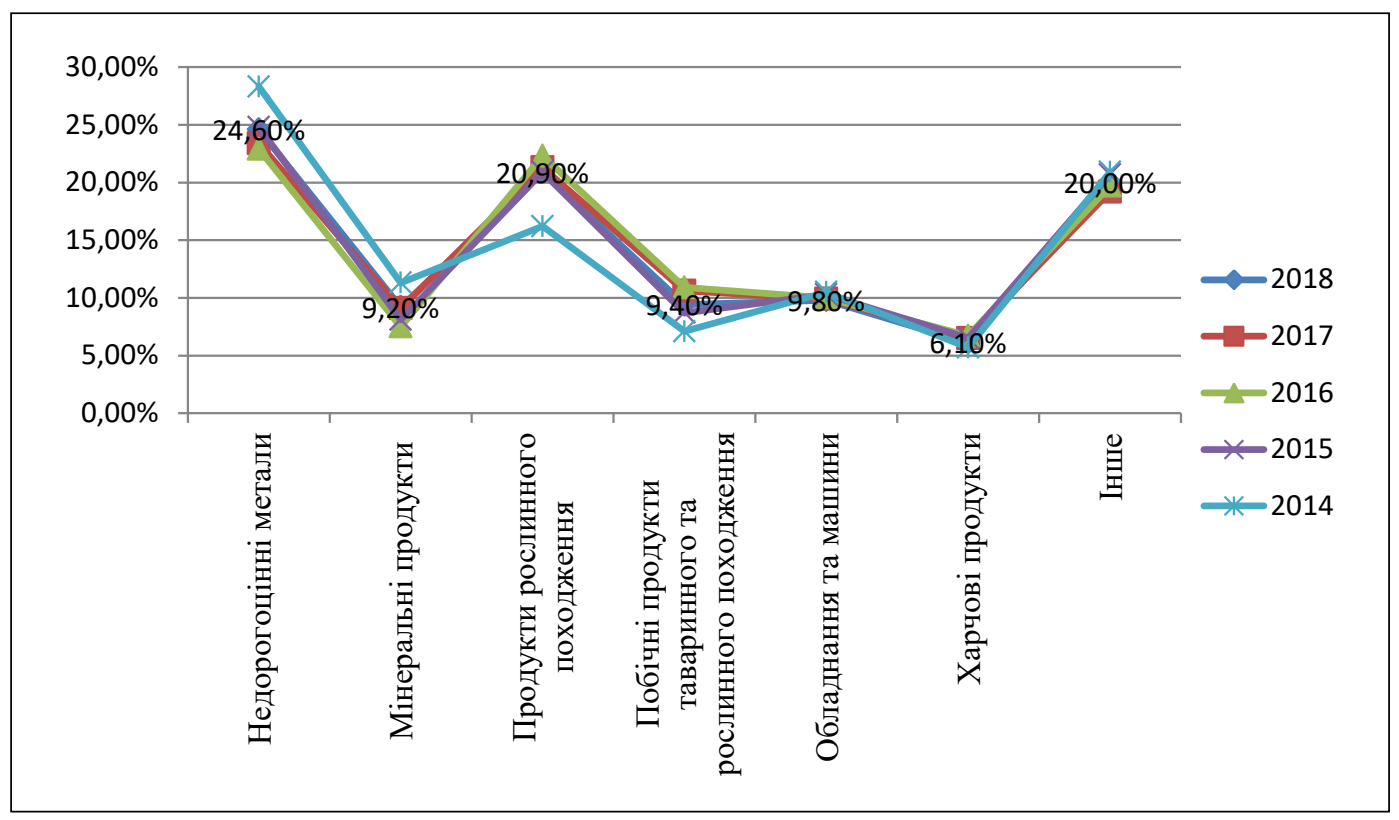

Рис. 3. Динаміка товарної структури експорту України за останні п'ять років [4] 


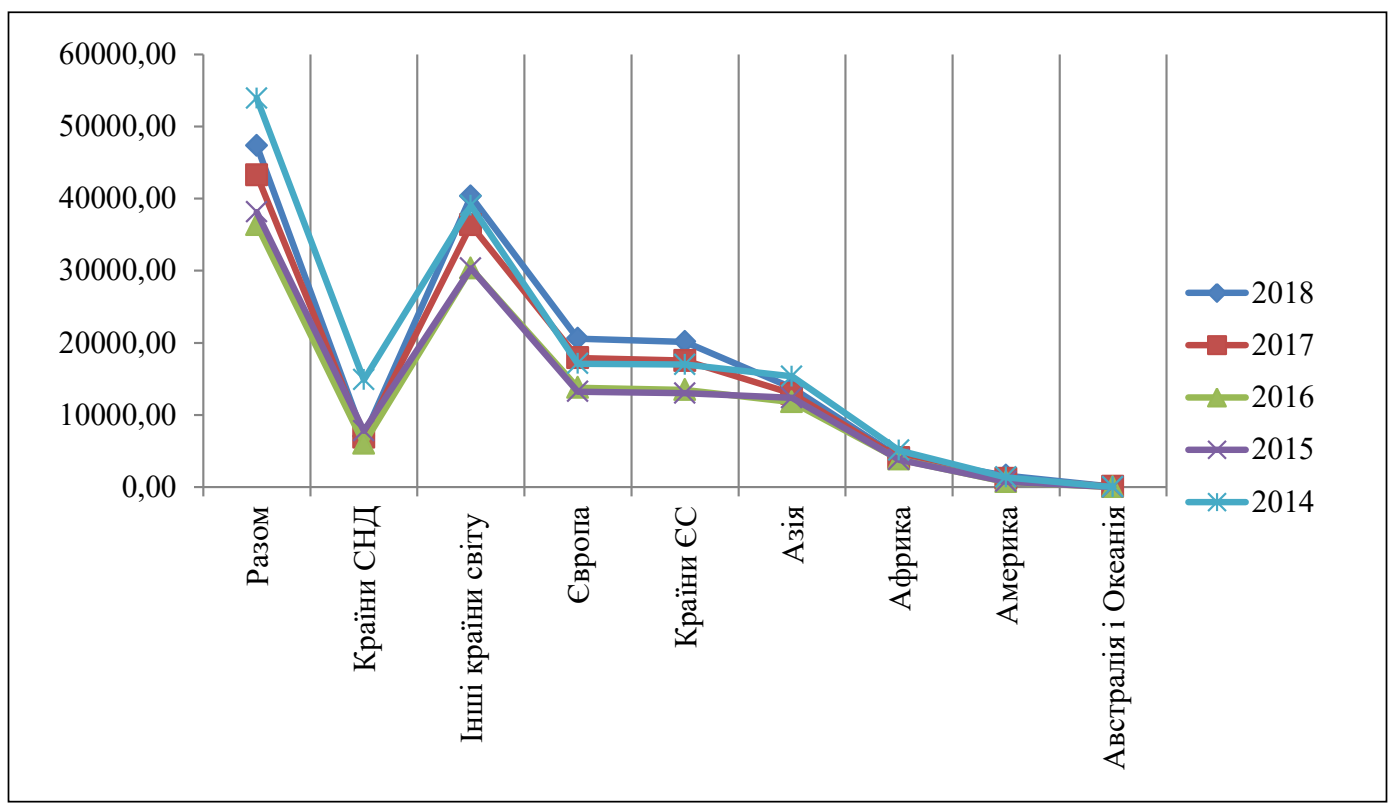

Рис. 4. Динаміка географрічної структури зовнішньої торгівлі товарами України за останні п'ять років, млн дол. США (експорт)

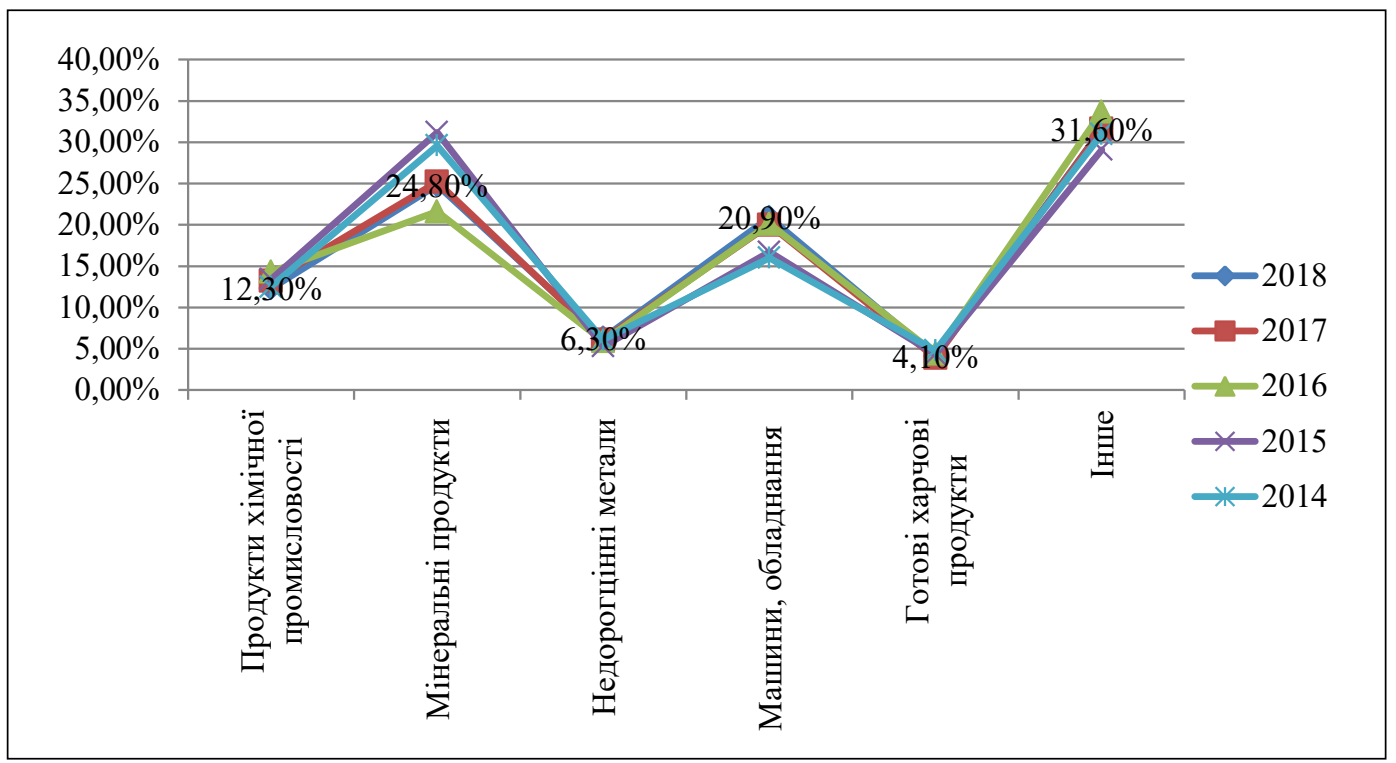

Рис. 5. Динаміка товарної структури імпорту України за останні п'ять років [4]

Можемо бачити, що питома вага торгівлі у період із 2014 по 2016 р. мала тенденцію до скорочення. Це пов'язано з подіями 2014 р. У 2015 р. експорт до країн СНД, зокрема й до Росії, зменшився на 90,64\% порівняно з 2014 р. і досі залишається рекордно низьким.

Водночас країна отримала можливість експорту товарів до країн Європейського Союзу без сплати митних зборів. Ми бачимо значне зростання порівняно $з$ періодом 2014-2016 рр. Частка експорту в 2017 р. становила 43264,70 млн дол. США, що на 15,9\% більше порівняно з 2016 р. Проте експорт до європейських країн, попри позитивні зрушення, не $€$ досить успішним через високу частку імпорту товарів із високою доданою вартістю. У 2018 р. загальний обсяг торгівлі товарами між Україною та ЄС становив 47 335,00 млн дол. США. Як і раніше, основними статтями експорту залишилися сільськогосподарська продукція та сировина.

Україна належить до країн із сировинним потенціалом, тобто експортує сировину за кордон, а там ії переробляють і повертають нам у вигляді готових імпортних товарів, що є вкрай неефективним. Отриману додану вартість конкуренти інвестують у нові виробничі потужності, натомість наша країна використовує отримані гроші на модернізацію інфраструктури для експорту сировини. Державі потрібно зрозуміти, що переробка сировини всередині країни може принести позитивні зрушення у живленні різних сорер економіки. 


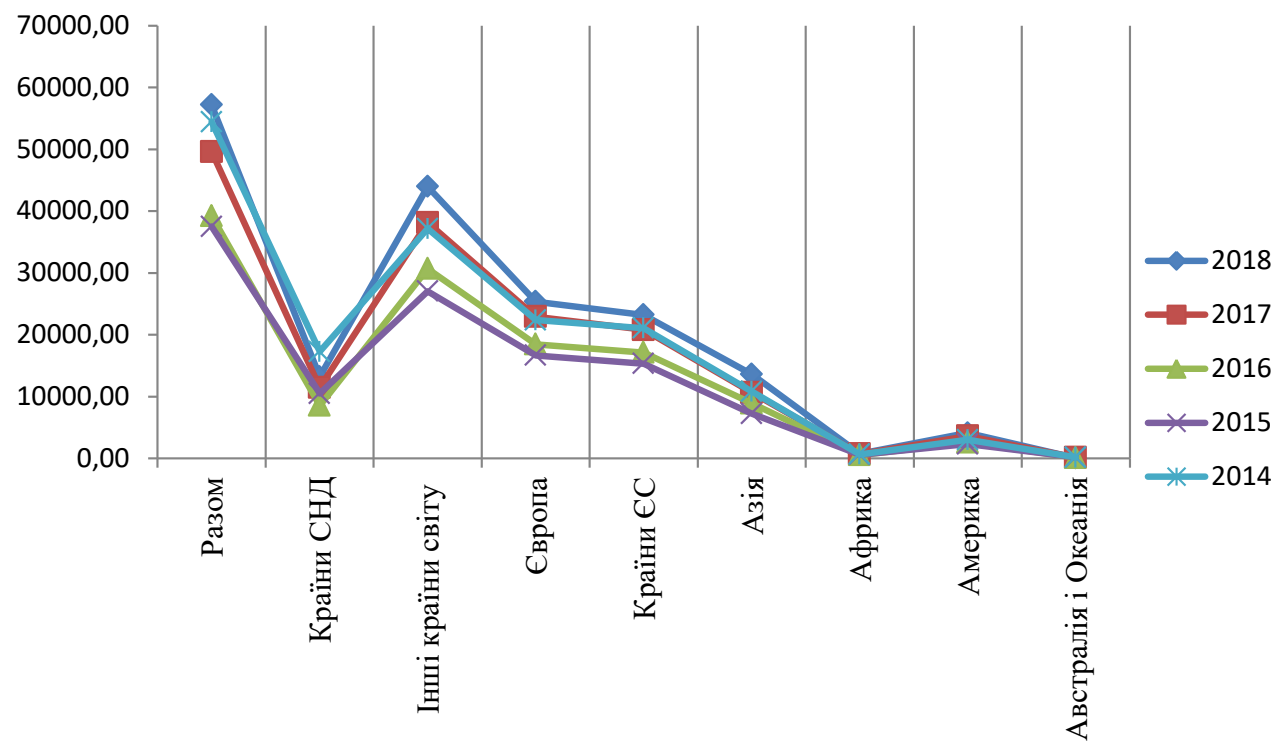

Рис. 6. Динаміка географрічної структури зовнішньої торгівлі товарами України за останні п'ять років, млн дол. США (імпорт)

Проаналізувавши товарну структуру імпорту, бачимо, що найбільше імпортних товарів припадає на мінеральні продукти, із них, за даними Державної служби статистики, 23,4\% - це мінеральні палива, нафта та продукти її перегонки; у 2014 р. дана стаття трималася на рівні 27,8\%. Друге місце займають машини, обладнання та механізми - 20,9\% у 2018 р., з яких 11,3\% припадає на ядерні реактори, котли та машини. Це вказує на те, що наша країна $є$ вкрай залежною від паливноенергетичного комплексу, а отже, і від країн-імпортерів. Значна частина припадає й на обладнання, машини, механізми. Усе це вказує на те, що наша країна використовує стратегію імпорту продукції.

Із представлених даних ми можемо спостерігати, що імпорт товарі зріс у 2018 р. на 13,25\% порівняно 32017 р. і $є$ найбільшим за останні п'ять років. Значно зросла частка імпорту з країн Європейського Союзу, імпорт товарів із країн ЄС зріс на 46,8\% порівняно 3 кризовим періодом 2015 р. Завдяки Угоді про асоціацію $3 \in С$ для України збільшилася роль країн Європи в торгівлі. Що стосується країн СНД, то ми бачимо значне зниження імпорту в період із 2015 по 2016 р., але нині імпорт із цих країн залишається значним передусім через залежність економіки країни від поставок енергоносіїв.

Висновки 3 проведеного дослідження. Спираючись на всі вищенаведені фракти, можемо стверджувати, що, змінивши вектор зовнішньоторговельних відносин, Україна значно поглибила співпрацю з країнами Європейського Союзу та Європи у цілому, що дало можливість переорієнтувати торгівлю з уже звичного ринку $\mathrm{CHД} \mathrm{та} \mathrm{Росії}$ та перейняти європейський досвід 3 актуальних питань у ссрері аграрного сектору. Проте український експорт усе ще залишається досить вузько спрямованим, що заважає говорити про перехід на високотехнологічні моделі виробництва. Ключовими статтями українського експорту все ще залишаються товари 3 низьким рівнем переробки або низькою доданою вартістю, що свідчить про вкрай неефективне використання природних ресурсів. Для збільшення темпів розвитку економіки України державі потрібна перебудова структури експорту. Сюди можна віднести виготовлення диверсисрікованих товарів і скорочення частки експорту сировини, виготовлення наукомістких товарів, а також нарощення темпів обсягу товарів із високою доданою вартістю. Усім відомий фракт, що країни імпортують товари, які не можуть виробляти самостійно, і в ідеальному варіанті експорт товарів повинен перевищувати імпорт. Що стосується України, то в останні роки зберігається негативна тенденція, коли імпорт перевищує експорт, як наслідок, сальдо торговельного балансу $є$ від'ємним.

Збільшення частки інвестицій, у першу чергу в комплекс АПК, допоможе модернізувати сучасну структуру сільського господарства, створити робочі місця з гідною заробітною платою та змінити негативну тенденцію, оскільки частка залучених іноземних інвестицій в агропромисловий сектор залишається незначною, наприклад у 2018 р. вона становила лише 1,7\% від загального обсягу інвестицій.

Місце експорту в економіці є значним, але аналіз тенденцій зовнішньої торгівлі показує значну залежність країни від імпорту енергоносіїв. Країні потрібен пошук альтернативних джерел 
енергії. У сучасному світі на перший план виходить неабияке занепокоєння про екологію. Пошук альтернативних джерел енергії дасть змогу створити позитивний імідж для країни, це можливість утілення в життя ідей молодого покоління, а також залучення значного обсягу іноземних інвестицій, що призведе до позитивних економічних зрушень. На даному етапі ми можемо лише стверджувати, що існує значний вплив із боку країн - експортерів продуктів паливно-енергетичного комплексу. Для зменшення залежності від впливу країн-експортерів доцільно використати стратегію імпортозаміщення паливної продукції, зокрема нафтти. Для подолання існуючих кризових явищ в економіці уряду країни потрібно проводити виважену політику щодо стимулювання власного виробництва продукції та модернізації уже існуючих підприємств.

\section{БІБЛІОГРАФІЧНИЙ СПИСОК:}

1. Касич А.О., Дідур С.В. Структурні характеристики зовнішньої торгівлі України. URL https://er.knutd.edu.ua/bitstream/123456789/2995/ 1/20161115 505.pdf (дата звернення: 25.12.2019).

2. Задоя А.О. Зовнішня торгівля України: сучасні масштаби, структура і тенденції. Академічний огляд. 2016. № 2(45). С. 110-117.

3. Калюжна Н. Зовнішня торгівля України: методологія дослідження. URL : http://zt.knteu.kiev.ua/ files/2017/01(90)/ZT_01_2017_st_02.pdf (дата звернення: 25.12.2019).

4. Товарна структура зовнішньої торгівлі у 2018 році : статистичні бюлетені. URL : https:// ukrstat.org/uk/operativ/operativ2018/zd/tsztt/tsztt_u/ tsztt1218_u.htm (дата звернення: 22.12.2019).

5. Основні показники зовнішньої торгівлі України. URL : http://ucab.ua/ua/doing_agribusiness/zovnishni rinki/osnovni_pokazniki_zovnishnoi torgivli_ukraini (дата звернення: 28.12.2019).

6. Експорт чорних металів: надходження від реалізації зросли майже на 22,6\%. URL : https:// www.unn.com.ua/uk/news/1727257-eksport-chornikhmetaliv-nadkhodzhennya-vid-realizatsiyi-zroslimayzhe-na-22-6 (дата звернення: 28.12.2019).

7. Експорт-2014: сумні тенденції. Де виграла і де програла Європа? URL : https://www.eurointegration.com.ua articles/2015/03/12/7031779/ (дата звернення: 28.12.2019).

8. Тенденції зовнішньої торгівлі товарами України 3 країнами Європи. URL : https://old.bank.gov.ua/ doccatalog/document?id=69463442 (дата звернення: 25.12.2019).

9. Віннічук Ю. Чому Україна бідна. URL : https:// biz.censor.net.ua/resonance/3117488/chomu_ukrana bdna (дата звернення: 28.12.2019).

10. Туніцька Ю.М. Проблеми розвитку зовнішньої торгівлі товарами України. URL : http://journals.uran. ua/index.php/2225-6407/article/view/95631 (дата звернення: 22.12.2019).
11. Дунська А. Експортно-імпортна діяльність України. URL : http://zt.knteu.kiev.ua/files/2016/3(86)/5. pdf (дата звернення: 22.12.2019).

\section{REFERENCES}

1. A.O. Kasych, S.V. Didur (2008) Strukturni kharakterystyky zovnishnoi torhivli Ukrainy [STRUCTURAL CHARACTERISTICS OF FOREIGN TRADE OF UKRAINE] Available at: https://er.knutd.edu.ua/bitstr eam/123456789/2995/1/20161115_505.pdf (accessed 25 December 2019).

2. Zadoy A.O. (2016) Zovnishnia torhivlia ukrainy: suchasni masshtaby, struktura i tendentsii [Ukraine's international trade: current scale, structure and trends] Akademichnyi ohliad. No 2(45) pp. 110. 117 (accessed 25 January 2019).

3. Kaliuzhna N. (2017) Zovnishnia torhivlia ukrainy: metodolohiia doslidzhennia [External trade of Ukraine: research methodology] Available at: http://zt.knteu.kiev.ua/files/2017/01(90)/ZT 012017 st 02.pdf (accessed 25 December 2019).

4. Tovarna struktura zovnishnoi torhivli u 2018 rotsi [Commodity structure of foreign trade in 2018] Statystychni biuleteni. Available at: https://ukrstat.org/uk/ operativ/operativ2018/zd/tsztt/tsztt_u/tsztt1218_u.htm (accessed 22 December 2019).

5. Osnovni pokaznyky zovnishnoi torhivli Ukrainy [The main indicators of foreign trade of Ukraine] Available at: http://ucab.ua/ua/doing agribusiness/ zovnishni_rinki/osnovni_pokazniki_zovnishnoi_torgivli ukraini (accessed 28 December 2019).

6. Eksport chornykh metaliv: nadkhodzhennia vid realizatsii zrosly maizhe na 22,6 \% [Exports of ferrous metals: sales revenues increased by almost 22.6\%]: Available at: https://www.unn.com.ua/uk/news/1727257-eksportchornikh-metaliv-nadkhodzhennya-vid-realizatsiyi-zroslimayzhe-na-22-6 (accessed 28 December 2019).

7. Eksport-2014: sumni tendentsii. De vyhrala i de prohrala Yevropa? [Export-2014: sad trends. Where has Europe won and lost?] Available at: https://www.eurointegration.com.ua/articles/2015/03/ 12/7031779/ (accessed 28 December 2019).

8. Tendentsii zovnishnoi torhivli tovaramy Ukrainy z krainamy Yevropy [Trends in foreign trade in goods of Ukraine with European countries] Available at: https://old.bank.gov.ua/doccatalog/document? id=69463442. (accessed 25 December 2019).

9. Y. Vinnichuk (2019) Chomu Ukraina bidna [Why Ukraine is Poor] Available at: https://biz.censor.net.ua/ resonance/3117488/chomu_ukrana_bdna (accessed 28 December 2019).

10. Y. Tunitska (2015) Problemy rozvytku zovnishnoi torhivli tovaramy Ukrainy [Problems of development of foreign trade in goods of Ukraine] Available at: http://journals.uran.ua/index.php/2225-6407/article/ view/95631 (accessed 22 December 2019).

11. Dunska A. (2016) Eksportno-importna diialnist Ukrainy [Export-import activities Ukraine.] Available at: http://zt.knteu.kiev.ua/files/2016/3(86)/5.pdf (accessed 22 December 2019). 